\title{
Influence of Selected Factors on Behaviour of Adolescents Involved in Political Violence
}

\author{
Godwin G. Ogbebor \\ Department of Counselling Psychology \\ Faculty of Education, Delta State University, Abraka, Nigeria \\ Tel: 234-703-831-7959_E-mail: akpesirink@yahoo.com
}

Received: November 3, 2011

Accepted: November 25, $2011 \quad$ Published: March 1, 2012

doi:10.5539/ijps.v4n1p218

URL: http://dx.doi.org/10.5539/ijps.v4n1p218

\begin{abstract}
The research is on "violence in politics among adolescents in the Nigerian society". The research problems were to find out why adolescents have become violent when they are involved in politics. Certain factors were selected for investigation. The purpose was to find out the relationship between these factors and violence in polition in order to make recommendation on limiting the influence of these factors. The study was guided by five (5) hypotheses based on the relationship of socio-economic status, age of adolescents, parental care, discipline and situational background of violence occurrence. The descriptive design was used for the study and data collected through questionnaire. The chi-square method was adopted to analyse data collected. Findings showed the relationship of these factors with violence in adolescents in politics. Recommendations were made based on the results of data analyzed and findings of the research.
\end{abstract}

Keywords: Politics, Violence, Adolescents

\section{Introduction}

Adolescents are children between age twelve and twenty-three among most communities in Nigeria and usually they are in their last lapse of secondary school or at the University and in other tertiary institutions. Those who are not in these education institutions are in the various communities training in one type of trade or the other. In Nigeria today, these adolescents have become tools in the hands of politicians as political hanger on, as they function as political thugs. In the tertiary institutions, many of them are involved in campus politics where they graduate into partisan politics. Before the military incursion into Nigeria politics and the civilian experiments that followed, violence was not a major factor in partisan politics.

But one can now observe that the situation is no more the same. Violence now characterizes the political scene and the adolescents are the major groups manipulated by these politicians. This situation has become a problem both in the tertiary institutions and in the outer society. Bell (2002) had earlier stated that the adolescents are vulnerable audience in violent behaviour, and it is this that makes the situation worrisome. But what are those factors that predispose them to these violent actions?

The situation presently is that these vulnerable adolescents are being used by politicians to feather their political nests. They use them for violent activities and pay them. Because of what these adolescents gain materially from their political violent actions; other youths want to join them and the situation has become dangerous to the society.

Ordinarily, politics should not be a violent human activity. The word politics comes from the Greek word "politikos" modelled on Aristotle's views of affairs of the State (Liddel \& Scott, 2008). Today, youths and adolescents are deeply engaged in violent clashes in politics. The university politics is no exception. Campus politics have become violent as it is in the outer society. This is the problem picture that has prompted this research; and this is why the factors that predispose them to violence have to be focused upon in this work.

It is often assumed that politics only occurs at the level of government and the state and must involve party competition. It is observed that it is at this point of competition that violence occurs. Lewis (2008) gives a traditional definition of politics. That it is the art and science of government that could be in the state, church, guild, and family. Liddel \& Scott (2008) say that politics occurs where people disagree about the distribution of 
resources and have at least some procedures for the resolution of such disagreements. They say that, it is thus NOT politics in the state of nature where people make war on each other in their own interests, shouting; rather than agreeing. Politics is absent in such cases where there is monolithic and complete agreement on the right and duties in a society. Liddel \& Scott also opined that politics as seen from the Greek word [Politikos] is a process by which groups of people make collective decisions. They state that politics consists of social relations involving authority or power and regulation of a political unit and the methods and tactics used to formulate and apply policy. Plato and Aristotle saw politics as ways in which to create an ideal society, to create a better society than that which is already present (Collins, 2008).

From the foregoing we can see politics as it relates to governance, party competition, argument on issues, and agreement on same; resulting in resolution of such issues. It is not politics in a state of war, shouting, monopolithic agreement. But, it is politics where there is collective decision.

Violent behaviour among adolescents may as well be in the characteristics of adolescents. This brings us to the intellectual, moral, physical, emotional and psychological development of adolescents. Zedina (2008) discussed the characteristics of the adolescent as follows: that they prefer interaction with peers, participate in real life situations, pre-occupied with self, have a strong need for approval, understands his personal abilities and challenge the authority of adults. He suggests that these adolescents are capable of being involved in direct experience related to participatory democracy and they take adults as role model, and are concerned about inconsistencies between values exhibited by adults in the society. Giedd (2008) says that the brain of the adolescent is related to his behaviour. To explain this, he says that his studies has shown that the human brain does not finish maturing until about age 25; and before then adolescent's prefrontal cortex is not fully developed. According to him, this section of the brain is responsible for complex thinking; and central impulses and adjusts behaviour accordingly. These findings suggest that adolescents do not biologically have the same abilities to control impulses, anticipate consequences, and make fully reasoned decisions.

The Royal College of Psychiatrists London says that adolescence is the time when people are involved in trying out new experiences, some of which may be risky or even dangerous. That young people can crave excitement in a way that most adults find difficult to understand and the exciting activities may be dangerous. These characteristics may explain partly the violence noticed among them.

Violence is also defined as an intentional behaviour aimed at causing either physical or psychological pain (Berkowitz, 1983). He says that violence is in two categories which include hostile and instrumental violence. Elliot, Robin and Beveley (2004) say that violence is a consequence of pain and discomfort, frustration, provocation and reciprocation, social exclusion, aggressive objects and imitation. American Federal Bureau of Investigation defined violence as the expression of physical or verbal force against self or others, compelling action against one's will on pain of being hurt. The bureau says that violence is used as a tool of manipulation and also is an area of concern for law and culture which makes attempts to suppress and stop it. That the word violence covers a broad spectrum as it can vary from between a physical altercation between two beings where a slight injury may be the outcome to war and genocide where millions may die as a result.

The causes of violent behaviour in humans are often topics of research in psychology and sociology. Is violence inherent in humans? Is it a primary characteristic? These are questions Perterson (2002) has asked. He says that there are other natural tendencies and mechanisms for cooperation that can keep conflicts in check to channel aggression and to overcome conflict and violence. He says that violence is often pursued as an antidote to shame or humiliation; and also used as a source of pride and a defence of honour especially among males who often believe violence defines manhood.

In relation to the violent behaviour in politics, one may review the nature of youth and violence. The American Federal Bureau of Investigation (2007) also says that official crime statistics reveal high rate of offence among young people, all over the world. It named political crime as one of these. Others include rape, assault and theft. At the school of Psychology at the Birmingham University, a link between violence viewed from a young age and youth violence effect was found. This was related to media violence specifying that these youths are vulnerable audience. Other links to adolescent violence were poverty, one-parent families, and a lack of parental care, and inconsistent discipline. The Bureau also stated that in the 1960s, UNESCO review stated that television viewing is a contributory factor to delinquency and crime. Research into the media and violence attempts to determine whether a link between consuming media violence and subsequent aggressive and violent behaviour exists. Fergrison and Kilbum (2009); Freedman (2002); Pinker (2002) and Savage (2004) have opined in their various research works that media researcher may have exaggerated the effects of media on violent behaviour among adolescents. Leaning on the social learning theory of Albert Bandura, this research severally conclude 
that since human beings learn by the process of modelling, media seem to have influence on youth violent behaviour. That through social learning processes there is a causal relationship between consumption of violent media and aggressive behaviour. But we need to note that although Bandura updated his theoretical perspective in terms of social cognitive theory, criticisms have flooded his findings. That debate on the merits of these theories is likely to continue (Freeman, 2003; Pinker, 2002; Olson, 2004 \& Savage, 2004). From the foregoing, we can conclude that violent behaviour is a combination of genetic and early social influence (including media).

Bandura (1983) states that watching violent films can increase the tendency to be violent in the viewers. Sepper (1997) says also that children see violent characters on the TV as heroes and imitate them; while Elliot (2004) suggested ways of reducing violent behaviour in children. He says that violence can be reduced through managing anger, apology, modelling of non-violent characters, training in communication and problem solving skills and empathy. In this research, efforts were made to find out the influence of certain factors in the Nigerian society that promote violence among adolescents.

\subsection{Research Problem}

The researcher had identified certain factors that may predispose adolescents to violent behaviour when such adolescents are involved in political activities in Nigeria. The factors included socio-economic status of the parents, the age of the adolescents, type of parental care, nature of discipline and the background setting in which these violent behaviour occur. The research investigated the relationship these independent variables have with violent behaviour in political setting. The independent variables investigated in relation to violence were socio-economic status, age of adolescents, parental care, type of discipline and background when violence occurs.

\subsection{Research Hypotheses}

Five research hypotheses guided the study. They were:

$\mathrm{Ho}_{1}$ : There is no significant relationship between socio-economic status and violent behaviour among adolescents involved in political activities.

$\mathrm{Ho}_{2}$ : There is no significant relationship between age of adolescents and resort to violent behaviour during political activities.

$\mathrm{Ho}_{3}$ : There is no significant relationship between parental care and adolescents' violent attitude during political activities.

$\mathrm{Ho}_{4}$ : There is no significant relationship between type of discipline and resort to violence among adolescents involved in political activities.

$\mathrm{Ho}_{5}$ : There is no significant difference between resort to violence during politics and outside politics among adolescents.

\section{Research Method}

\subsection{Participants}

The population for the study was the adolescents in tertiary institutions and those outside the institutions in Delta State Nigeria. Conventionally, this can be put at $20 \%$ of the entire Delta State population of 2.5 million people. The population for this study is therefore about five hundred thousand $(500,000)$ adolescents. This population is made up of both male and female adolescents between age twelve and twenty-three years.

The sample was five hundred (500) adolescents made up of both male and female. This was got from the three senatorial districts of the State on equal basis per district. The researcher used stratified and cluster sampling techniques. Every senatorial districts was used as a cluster and in each of these, two stratums were identified. These were those in tertiary institutions and those adolescents outside tertiary institutions.

\subsection{Materials}

The instrument used for this study is the questionnaire. The items in the questionnaire were related to the research problems and the hypotheses that guided the study. Since the topic is related to violence in politics, and the research problems also related to causes of violence, violence in politics and adolescents involvement, the items in the questionnaire were drawn up around these variables. The questionnaire was made up of fifteen items. The responses were got through the use of numerical rating scale with four alternatives that are indicators of the relevant variables.

To ensure validity, the instrument used represented the content of interest, that is, all the independent variables as they relate to the dependent variable. These include violence, adolescents, age of adolescents, parental 
influence and discipline. The scoring method was void of bias and all spurious variables controlled. So, the scoring and tallying of responses was done by the researcher only; and the respondents were those adolescents involved in politics, male and female within the adolescent age bracket. Each of the items on the questionnaire measured specific traits and constructs. To ensure reliability the researcher used the test-retest method. To ensure this, the questionnaire was administered twice to the same group of individuals and the paired score correlated before administering them to the five hundred (500) respondents.

\subsection{Design}

The design used was descriptive survey where respondents were given the questionnaire to respond to. Responses were elicited covering the independent variables of socio-economic status, age brackets of adolescents, parental care, type of discipline and background where behaviour occurred. The questionnaire had a total of twenty items with about four to five related to a particular variable.

\subsection{Statistical Model}

The statistical model used in the work to analyse the data is the parametric statistics. Specifically, the chi-square method was adopted. This is adequate since in each of the hypothesis, a comparison of two means were involved. This was adopted through hypothesis one to five. Each hypothesis was tested at 0.05 level of significance.

\subsection{Result}

The result revealed relationship between the independent variables investigated and adolescents' involvement in political violence. This was shown in the findings of the first four hypotheses that were tested. These were:

$\mathbf{H o}_{1}$ : There is no significant relationship between socio-economic status and violent behaviour among adolescents involved in political activities.

The result as seen in Appendix I table I indicates that the calculated $\mathrm{x}^{2}$ value of 25.03 is more than the critical $\mathrm{x}^{2}$ value of 3.84 at 0.05 level of significance. The null hypothesis is therefore rejected. The result shows that there was a significant relationship between adolescents' socio-economic status and violent behaviour in politics.

$\mathbf{H o}_{2}$ : There is no significant relationship between age of adolescents and their resort to violent behaviour during political activities.

The result in Appendix I table II shows that the calculated $x^{2}$ value of 331.28 is more than the critical $x^{2}$ value of 3.84 at 0.05 level of significance. The null hypothesis is rejected. The result indicates a significant relationship between age of adolescents and resort to violent behaviour in politics among adolescents.

$\mathrm{Ho}_{3}$ : There is no significant relationship between adequate parental care of adolescents and resort to violent behaviour when involved in political activities.

The result in Appendix I table III shows that the calculated $\mathrm{x}^{2}$ value of 365.55 is more than the critical $\mathrm{x}^{2}$ value of 3.84 at 0.05 level of significance. The null hypothesis is rejected. The result revealed that there was a significant relationship between adequate parental care and violent behaviour in politics.

$\mathbf{H o}_{4}$ : There is no significant relationship between type of discipline and resort to violent behaviour in politics.

The result in Appendix I table IV shows that the calculated $x^{2}$ value of 16.87 is more than the critical $x^{2}$ value of 3.84 at 0.05 level of significance. The null hypothesis is therefore rejected. The result shows that there was a significant relationship between children discipline and resort to violence.

Ho$_{5}$ : There is no significant difference in resort to violence between adolescents in politics and outside politics.

The result in Appendix I table V shows that the calculated $x^{2}$ value of 454.82 is more than the critical $x^{2}$ value of 3.84 at 0.05 level of significance. The null hypothesis is therefore rejected. The result indicates that there was a significant difference between adolescents' violence behaviour in politics and violent behaviour outside politics.

\section{Discussion}

The research set out to investigate the aspects of violence among adolescents during political activities in the present Nigerian environment. The objective was to find out why Nigeria adolescents have become violent in politics both in partisan and campus politics. The study was carried out using the process of investigating certain factors related to pre-disposition of people to violence. The factors identified for study were socio-economic status of parents of adolescents, the age bracket of adolescents, type of parental care, nature of discipline and situational background of the occurrence of violence whether during political activities or outside political activities. 
Five hypotheses were formulated to guide the study, and the findings as seen in hypotheses one to five showed that:

1) Socio-economic status of parents of adolescents is significantly related to resort to violence by adolescents during political activities. But here, adolescents from lower economic group were observed to show higher rate of violence.

2) The age bracket whether early adolescence (12-16years) or late adolescence (17-23years) is significantly related to display of violence in politics. While both age groups showed evidence of violent behaviour, the older ones were observed to be more involved in the display of violent behaviour.

3) Parental care was observed to be significantly related to display of violent behaviour. While children who had adequate parental care were observed to show violence, those with inadequate parental care indicated higher rate of violence in politics.

4) The type of discipline children have in their homes was also seen to be significantly related to show of violence among adolescents in politics. It was evident that adolescents who had strict discipline in their homes showed less violent behaviour during political activities compared to those who had less discipline.

5) The background in which adolescents showed violence whether during political activities or outside political activities was also studied. The observation was that they showed more violence during politics than they showed outside politics.

Elliot, Robin \& Beveley related violent behaviour among youths to frustration among other factors. This research has found that low socio-economic status of parents of adolescents (a frustrating factor) has significant relationship with violent behaviour. The finding in this research agrees with that of Perterson (2002) who states that the shame experienced by adolescents from poor parents is a factor that predisposes them to violent behaviour.

The American Federal Bureau of Investigation (2007) had reported that the School of Psychology at Birmingham University found a link between violent views and young age; also a link between poverty and violent behaviour. These findings agree with some of those in this research. This same Federal Bureau of Investigation also states that lack of parental care and inconsistent discipline pre-dispose youths to violent behaviour. These views agree with the findings of this research also. The findings here states that there are significant relationships between types of discipline and parental care and violent behaviour during political activities among adolescents.

Bell (2002) and Zedina (2008) reported that adolescents are naturally vulnerable to violence. Bell's view and those of Zedina did not specifically identify at what age of adolescence the vulnerability occurs most. But this research went further to find that older adolescents $(17-23)$ years show more violent behaviour during political activities. This result may have been influenced by the fact that older adolescents were more involved in political activities. On the situational background that may favour violent outburst by adolescents, the research found that this is more during political activities than during normal daily activities. This result may have been influenced by the nature of the political atmosphere; where politicians are desperate to use adolescents from poor homes background to violently assist them falsify election results for example.

The findings of this research on the influence of socio-economic status and age of adolescents in relation to violent behaviour agree with those of bell (2002) and Liddel and Scott (2008). Bell says that adolescents are naturally vulnerable to violence. Liddel and Scott support Elliot, Robin and Beveley in their views that socio-economic status is one of the factors that influence adolescents in resorting to violence.

In this research we found out that older adolescents are more violent compared to younger adolescents. This agrees with Zedina's findings that biological stage of the brain development of adolescents affect their violent reaction to issues. This may account for why they are vulnerable to violence (Bell, 2002).

\subsection{Implication}

The finding of this research has implications for the Nigeria society. There is evidence that adolescents show more violence during political activities than they show outside politics. It becomes necessary to discourage violence in politics. This can be done through legislation. Also when such laws are enacted, and electoral acts promulgated, the influences of socio-economic status, age of adolescents, parental care and type of discipline on violent behaviour will be minimised.

\subsection{Recommendations}

From results of data analysed and findings in the research, the following recommendations are made: 
1) Older adolescents should be monitored in institutions of higher learning in the aspects of violence. Debates on ways of peaceful resolutions of disagreements should be organised. Films, and drama or plays of peaceful resolutions of disagreements should be encouraged.

2) Teachers, school authorities and parents should encourage strict discipline in homes and in schools. In this work, children with adequate parental care and strict discipline have been seen to resort less to violence and are less predisposed to it.

These recommendations agree with those of Brelm, Kassin and Fein (2005) who say that in order to reduce violent behaviour the society should reward non-violent behaviour, display attractive and non-violent models, reduce violent punishment in schools and in the society, reduce access to and display of weapons, learn to apologise and develop good communication skills.

3) The school and society should appreciate the vulnerability of adolescent in violence and commit them less in situations that may result in violence such as political activities. If they must be involved in political activities, they must be carefully monitored.

\section{References}

Bandura, A. (1983). Psychological mechanisms of aggression. In R.G. Green and E. L. Dennerstein (Eds) Aggression: Theoretical and Empirical Review. Vol. 1. New York: Academic Press.

Bell S. C. (2002). A Research Agenda for DSM-V American Psychology Association.

Berkowitz S. R. (1983). Media and Violence: A Cross National Comparison. Hillsdale N. J. Lawrence Eribaum Associates.

Brebin, S. S., Kassin, S., \& Fein, S. (2005). Social Psychology (6 ${ }^{\text {th }}$ Ed). New York, Houghton Mifflin Company. Collins E. (2008). English Dictionary. Retrieved from online Etymology.

Elliot, M., Robin, C. E., \& Beveley, K. (2004). Television and the aggressive Child. A cross national comparison. Hillsdale.

Fergrison, C. J., \& Kilbum, J. (2009). The Public health of risks of media violence: A meta-analytic review. Journal of Pediatrics. [Online] Available: http://www.tamin.Edu./cfegason/MVJPED

Freedman, J. L. (2002). Media violence and its effects on aggression: assessing the Scientific evidence. Toronto: University of Toronto Press.

Giedd, J. (2008). Characteristics of Adolescents. Adolescent Brain Development and Drug Abuse. Philadelphia: Treatment Research Institute.

Lewis, C. T. (2008). Political Dictionary. Perseus Digital Dictionary. [Online] Available: http://www. Everything 2.com

Liddel, H. G., \& Scott, R. (2008). Peruses Digital Library. [Online] Available: http://www. Everything 2.com

Olson, P. (2004). Learning Based Media Effects Theories. Criticisms of Media Violence Research.

Perterson, J. (2002). The public health risks of media violence. A meta-analytic review. Journal of Pediatrics. [Online] Available: http://www.MV.JPE.Pdf

Pinker, E. (2002). Criticisms of media Violence. Research journals of media violence effects. 62, 461-464. Savage, C. E. (2004). Learning - Based Media Effects Theories. Reply Letter to the Editor, IGN. J., July 28, Retrieved Feb. 27.

Sepper, S. I. (1997). Media Influence on Behaviour among adolescent. Journal of media violence effects, 62, $371-375$.

The American Federal Bureau of investigation (2007). Youth and Violence. Wikipedia, the free Encyclopaedias.

Zedina (2008). Adolescence, Brain Development and Legal Culpability. Washington, D. C. Juvinite Justice Centre. 
Table 1. Chi-square $\left(\mathrm{x}^{2}\right)$ analysis of socio-economic status (SES) and resort to violent behaviour in politics

\begin{tabular}{|c|c|c|c|c|c|}
\hline Adolescents & Obs & Exp. & $\begin{array}{l}\text { Calculated } x^{2} \\
\text { Value }\end{array}$ & $\begin{array}{l}\text { Critical } \\
\text { Value }\end{array}$ & $\begin{array}{l}\text { Decision at } \\
0.05\end{array}$ \\
\hline Upper SES Exposed to violence & 70 & 55 & \multirow{2}{*}{25.03} & \multirow{2}{*}{3.84} & \multirow{2}{*}{ Rejected } \\
\hline Lower SES Exposed to violence & 430 & 345 & & & \\
\hline
\end{tabular}

Table 2. Chi-square $\left(\mathrm{x}^{2}\right)$ analysis of age of adolescents and violent behaviour in politics

\begin{tabular}{|l|l|l|l|l|l|}
\hline Adolescents & Obs & Exp. & $\begin{array}{l}\text { Calculated } \mathbf{x}^{2} \\
\text { Value }\end{array}$ & $\begin{array}{l}\text { Critical } \\
\text { Value }\end{array}$ & $\begin{array}{l}\text { Decision at } \\
\mathbf{0 . 0 5}\end{array}$ \\
\hline $12-16$ years & 200 & 60 & 331.28 & 3.84 & Rejected \\
\hline $17-23$ years & 300 & 265 & & \\
\hline
\end{tabular}

Table 3. Chi-square $\left(\mathrm{x}^{2}\right)$ analysis of adequate parental care and violent behaviour

\begin{tabular}{|l|l|l|l|l|l|}
\hline Adolescents & Obs & Exp. & $\begin{array}{l}\text { Calculated } \mathbf{x}^{2} \\
\text { Value }\end{array}$ & $\begin{array}{l}\text { Critical } \\
\text { Value }\end{array}$ & $\begin{array}{l}\text { Decision at } \\
\mathbf{0 . 0 5}\end{array}$ \\
\cline { 1 - 6 } Adequate Parental care & 350 & 150 & 365.55 & 3.84 & Rejected \\
\cline { 1 - 4 } & 150 & 68 & & 34 \\
\hline
\end{tabular}

Table 4. Chi-square $\left(\mathrm{x}^{2}\right)$ analysis of children discipline and resort to violent behaviour during political activities

\begin{tabular}{|l|l|l|l|l|l|}
\hline Adolescents & Obs & Exp. & $\begin{array}{l}\text { Calculated } \mathbf{x}^{2} \\
\text { Value }\end{array}$ & $\begin{array}{l}\text { Critical } \\
\text { Value }\end{array}$ & $\begin{array}{l}\text { Decision at } \\
\mathbf{0 . 0 5}\end{array}$ \\
\hline Those with strict discipline & 205 & 50 & 16.87 & 3.84 & Rejected \\
\hline Those without strict discipline & 206 & 12 & & 164 \\
\hline
\end{tabular}

Table 5. Chi-square $\left(\mathrm{x}^{2}\right)$ analysis of adolescents' use of violence in and outside political activities

\begin{tabular}{|l|l|l|l|l|l|}
\hline Adolescents & Obs & Exp. & $\begin{array}{l}\text { Calculated } \mathbf{x}^{2} \\
\text { Value }\end{array}$ & $\begin{array}{l}\text { Critical } \\
\text { Value }\end{array}$ & $\begin{array}{l}\text { Decision at } \\
\mathbf{0 . 0 5}\end{array}$ \\
\cline { 1 - 4 } & 88 & 70 & 454.82 & 3.84 & Rejected \\
\hline Violence outside politics & 206 & 12 & & 24 \\
\hline
\end{tabular}

